Journal of Law \& Social Studies (JLSS)

Volume 2, Issue 1, pp 20-25, 2020

www.advancelrf.org

\title{
Agitational Politics Impacts On National Institutions: A Case Study Of Khan's Agitation 2014
}

\author{
Khadija Murtaza \\ PhD Research Scholar, \\ Department of Political Science \& IR, \\ GC, University Faisalabad, \\ Email: khadijamurtaza12@yahoo.com \\ Dr. Mian Muhammad Azhar \\ Assistant Professor, \\ Department of Political Science \& IR, \\ GC, University Faisalabad, \\ Email: muhammad.azhar@gcuf.edu.pk
}

\begin{abstract}
Politics is all about power in a democratic form of government. In a democracy, agitation is the part of politics in the developmental stage of human rights. Agitational politics is a kind of politics which urge the public demands and utilize the public opinion for the sake of specific issue. Sometimes, it would make public violent who acts as attacking the police and damaging the official establishments. Protestors cover the specific area and refuse to move on until their demands are measured by authorities. It affects the working of government institutions and also creates political instability. The main reason behind this, agitational politics, have lack of stout and genuine leadership in Pakistan. Agitational politics is a strategy used by the opposition that indirectly creates a weak situation for democracy. In agitational politics, parties and groups make use of speeches and public opinion to gain public support. This article discusses the dharna politics of 2014 arranged by the rising political party Pakistan Tehrik-e-Insaf which directly disturb the political activities and also the reason of cancelation of the visit of foreign officials of different countries. This research paper will cover the impacts of agitational politics on the working of the institution. This work also explains that, how sit-in politics damage the state working institutions and also destabilize the democracy. Sometimes it strengthens the political system but most of the time it creates uncertainty in the political environment. It is the utmost scuffle that weakens the civil and national institutions and democracy faces a lot of dares.
\end{abstract}

Key words: agitation, civil disobedience, accountability, national institutions, public opinion

\section{Introduction}

In democratic political system supreme power is vested in the people and power is directly exercised by an elected representative by people. In other words, Politics is all about power and achieving a position for public development and safety. Our political framework has been rendered broken as the chosen heads have disregarded the basic component of welfare for the public. Moreover, they seek to power to promote their personal interest rather than for the safety of people. The intense political confrontation between the government and the public always creates a worse situation for the country. Pakistan movement is a fine example of an agitational movement that unites the Muslim and got independence. Alike this movement, the incident of Jalliyanwala bagh took place in 1919 when people were gathered for nonviolent protest for the deportation of national leader Satya pall and Saifudin Kitchlew. The British Indian Army under the direction of Acting Brig-Gen Reginald Dyer discharged rifles into a horde of Punjabis who had accumulated in Jalliyanwala Bagh, Punjab. The peaceful protest turned into bloodshed by the British Indian Army. The political stability of the nation is the essential element for the country's development. After the independence of Pakistan, it faces a lot of ups and downs in political spheres. The death of Quaid-e-Azam and assassination of Liaqat Ali khan creates a blank space for the mature leadership in Pakistan. Pakistan faced 
almost half of its life in instability in politics, regime changes, and constitutional issues. Agitational politics, is the part of democracy, is a system in which propaganda and agitation are used as a tool to influence public opinion. Any party or opposition group agitates against the policy or decision that legislates by the administration when their demands are not considered by them.

Albeit the two dissents leaders have kept up inflexible requests that Prime Minister Sharif leave office, their more extended term targets contrast, and has been mindful so as not to relate legitimately with the other. The agitational activities have obviously banned the everyday life exercises in Islamabad yet have for all intents and purposes deadened the capital politically and economically. These activities seem to have put Pakistan political stability and economy under obstruction as well as security concerns. Agitations and marches play havoc with our economy and psyche. Indeed, Security and stability are two fold concerns for the foreign countries to invest in Pakistan for development. In this way, the challenges and street agitations do not appear to profit the present economy. There were no unmistakable indications of a coordinated effort between the Pakistan Tehreek e Insaf and Pakistan Awami Tehreek ahead of the pack up to the challenges, aside from their consenting to a fundamental four-point motivation on regarding vote based system and the Constitution.

Khan's Demands:

1) No negotiation until Nawaz resignation

2) Reelection under new electoral reforms

3) Caretaker setup should be independent

4) May 11, 2013 vote fraudsters must be punished (News, 2014)

Agitational politics of PTI and PAT by Imran khan and Tahir ul Qadri is the fine example that halts the working of state's institutions and highlighted the weak leadership and role of political parties. They were not agreed to quit their protest until their demands are not considered. On 15 August 2014, a populist opposition party PTI announced anti-government protest against the Sharif's government. Near about thousands of protestors were marching under the leadership of Imran khan arrived in Islamabad. The followers of Tahir ul Qadri were also demonstrating in the heart of the capital of Pakistan. The party of Tahir ul Qadri has no governmental representation but gathered a huge crowd against the government. Pakistan Tehreek I Insaaf holds about $10 \%$ of all National Assembly situates and furthermore drives an alliance government in the Khyber Pakhtunkhwa commonplace capital of Peshawar. Khan's Azadi tramp is the most recent articulation of famous resentment regarding year-old charges that the 2013 decisions were fixed by PML-N. The PTI dissent has looked to constrain Sharif's renunciation and in this way dispatch national decisions under the sitting government. Also, Khan has requested broad discretionary changes and arraignment of those engaged with the supposed vote-fixing (Kronstadt \& Kumar, 2014)One needs to think about the outcomes of this persevering and vain agitation. Imran khan, chief of PTI, denied canceling the dharna and rejected the revealed affirmation by the Chief of Army Staff for the usage of the development of a Judicial Commission reported by the Prime Minister. With an end goal to acquire PTI's open dissent, Prime Minister Sharif had offered the concession of shaping another race survey board made out of Supreme Court judges, however, Khan has stayed unbending in his interest that Sharif leaves. After the principal week, Imran Khan's challenge walk seemed to lose energy, with his requests getting to be conflicting and his general procedure unclear. He set various 48-hour due dates for Sharif's acquiescence, just to alter his opinion. Imran Khan's faltering activities and requests estranged him from vast swaths of the nation's media and made divisions inside his party (Akhter, 2015).

\section{Objectives of the Study}

The objectives of this research paper remain with two fundamental targets. Firstly, this paper is aimed to discuss about the agitational activities or sit-in politics and how these protests and dharna activities influence the state institutions. Secondly, how these activities affect the country image internationally.

\section{Research questions}

- How agitational politics affects the democracy?

- Whether or not the sit-in politics deteriorate the democratic institution?

\section{Research Methodology}


Political process theory is also known as political opportunity theory which offers a clarification of the conditions, attitude, and activities that make a social development fruitful in accomplishing its objectives and goals. Political process theory (PPT) is viewed as the center theory of social movements and these movements can be political and social. The purpose of this theory is how to mobilize and create a change through movements and protests. It focuses on the collaboration of points of movement such as organizational arrangements and political and economic factors. In political process theory, political opportunities and chances means the achievement of the movement is unimaginable without the political opportunities. Political opportunities exist when the framework experiences vulnerabilities and intervention inside the current political framework. In this procedures, framing are done by leaders of an organization or political party so as to enable the gathering or movement to openly and influentially depict the current issues and problems, then articulate these demands and describe why change is fundamental. But without any vision and idea political protests or public agitation is fruitless.

\section{Agitational Politics and working of Democratic Institutions}

After the independence of Pakistan, military and civil institutions frequently depend on political leaders and their slogans and orotundity besides the political reality like other democratic developing countries of the world. During agitational movements, leaders use different slogans to motivate as well as to unite the public to fulfill their goals. These slogans are based on issues and according to the situation. No doubt agitations deteriorate the political system but most of the time it strengthens the public on a specific issue. Alike before the formation of Pakistan, the famous slogans like Pakistan Ka Matlab Kya La Ilahah Illalah, Pakistan Zindabad, and Ban Kay Rahy Ga Pakistan were used. After autonomy of Pakistan, Zufiqar Ali Bhutto offered bend to political talk and his motto Roti Kapra Aur Makan which is still prevalent among the Pakistanis. There are other famouse slogans of Pakistani political rhetoric like the slogan of Nawaz Sharif's Qarrz Utaro Mulk Sanwaaro, General Pervaiz Musharraf's Enlightened Moderation and Sab Se Pahlay Pakistan, Asif Ali Zardari's slogan Pakistan Khaapay, Imran Khan's different slogans Tabdeli Akar Rahy Gi, Tsunami aa rahi Hay, Naya Pakistan, Azadi March and Tahir ul Qadri's Inquilab March etc. Politician's interest to arrange sit-in or agitation on governmental issues has underestimated the holiness of parliament yet, in addition, debilitated the trust of masses on majority rule organization. As open agents they do not focus and check out parliament's procedures to feature and resolve issues of open intrigue, along these lines, governmental issues of disturbance get help in Pakistan. Besides, the pattern of fomentation and violence has additionally isolated society into two sections. One group including Pakistan Tehreek e Insaf, Pakistan Awami Tehreek, Pakistan Muslim League and Awami Muslim League (AML) bolster unrest and need uncommon changes in the framework by toppling the sitting government while the other fragment driven by decision party Pakistan Muslim League -N alongside other resistance groups including Pakistan People's Party Parliamentarians underpins status quo to keep existing majority rule framework. It is fascinating that after the impact of Panama spills on the issue of seaward organizations alongside PTI, PPP preceded to onward the method for show. The administration of Pakistan Tehreek e Insaf, and even Pakistan People's Party-led huge open gatherings and requested Nawaz Sharif to venture down. Indeed, even after the exclusion of Nawaz Sharif as Prime Minister in the hands of Supreme Court of Pakistan under the petitions recorded by the PTI, Awami Muslim League and Jamat-Islami on the issue of Panama releases, habitual pettiness is as yet going on in the governmental issues of Pakistan.

Politicians as opposed to fortifying the vote base organizations for example parliament as a gathering to use for raising and tending to issues of national intrigue, pursue the way of fomentation and exhibit. They want to take issues of emergency and discretionary changes on streets and media to put weight on the administration. PTI's Azadi March and PAT's Inqilab March in front of parliament are main examples of agitational politics. Representatives of political parties, pressure groups or other associations have used the slogans to stimulate and stir the public opinion. Public opinion is itself, a part of democracy. By this way, they set the mood of the citizenry about a specific issue and highlighted the public opinion for self-interest. Political irresponsibility led the country towards the agitational activities and furthermore this may reason for Politician disregards the parliament. As a result of segments of intolerance in authoritative issues, leaders could not find understanding and appropriate courses of action. Agitation and politics of revolting negatively sway (impact) the internal and external environment of Pakistan.

The working of civil and political institutions is affected by agitational movements. Parliamentarians not properly pay consideration to the session of house and also the behavior of opposition party disturb and divert the attention. The member of opposition party chose the way to get their points as a street politics and agitates in the capital city of Pakistan but they forgot that the consequences of these agitations directly affect the image of Pakistan in all spheres of development in the world. By these agitational activities, they have directly weakened the working of national institutions and damaged the image of Pakistan around the world. 


\section{Foreign relations and trade}

There is not a smidgen of uncertainty that the ongoing advancements in Islamabad have influenced the nation's financial advancement, causing immediate and backhanded, quantifiable and tremendous misfortunes. The financial expenses of the emergencies since fourteenth August has surpassed rupee 1300 billion and in the context of political relation the cost of this instability with other countries and international institutions is tremendous (Ahmad, 2014).

The agitational movement, composed by Imran Khan's PTI and Tahirul Qadri-drove PAT, has canceled the visit by Sri Lankan and Maldives heads of state to Pakistan (Javed \& Mamoon, 2017). Due to protest, the Chinese president postpones his high-profile visit to Pakistan and set to visit India which strengthens the hands of universal powers that would prefer not to see close ties among Pakistan and China, the Chinese reshuffling in plans translated as isolation for Pakistan. Amid the visit, the Chinese head of state was required to sign a few resistance and financial settlements. Turkish President Recep Tayyip Erdogan landed in Islamabad on Wednesday evening on a two-day visit in November 2016(DAWN, 2016). But Pakistan Tehrik-I-Insaf (PTI) has chosen to refuse Turkish President Recep Tayyip Erdogan's discourse to the joint session of parliament, to be held after the visit to Pakistan. The reason for this boycott was given by party vice chairman Shah Mehmood Qureshi that the session held under a controversial Prime Minister Nawaz Sharif facing a charge of corruption. The trading of perspectives between the pioneers will cover a scope of respective relations just as local and global issues (Wasim, 2016). In this respects, one thing that the administration of these ideological political parties is to utilize political talk as an instrument on which sometimes they try depend to gain public support on different issues. It has turned into a pattern in Pakistani governmental issues that open intrigue issues are not adequately bantered in the parliament and resultantly delays in important enactment is seen.

Due to these agitational activities, the universal picture of Pakistan has impressively been broken. The political instability is straightforwardly influenced financial development. Remote financial specialists do not put resources into nations where there is polite war, overthrows; armed force takes over and so forth. Political precariousness additionally constrains inward speculation. By and large, they abstain from putting resources into their very own nation inspired by a paranoid fear of nationalization of their undertaking, vast scale meddles of activist, worker's guild and unforgiving frame of mind of different government organizations. The wealthy individuals including the lawmakers like to story their cash outside the nation or need to contribute out of their own nation. The creating nations are denied speculation subsidizes which seriously impact monetary development.

\section{Security Concerns}

Pakistan has endured security concerns since its commencement by both internal and external elements in the form of terrorism, sectarianism, and confrontation between federal and provinces. After its independence, no one country in the world is entangled in this type of threats as Pakistan faces today. Due to internal political instability, in Pakistan, external threats are boosted by them which create the threating situation for the survival of a country. Corruption, lack of accountability, political immaturity, racial and dogmatic conflict, and poor law and order situation are the major issues that lead to political instability and political agitation. All of these factors directly influenced the progress and prosperity of Pakistan's economy. These conditions are prompting political insecurity which throws a long and regularly damaging shadow on each country building action in the nation, hampering our financial thriving and advancement. Agitational activities by Pakistan Tehreek e Insaf and Pakistan Awami Tehrik budget of defense and security suffered a lot. The extra expense of security has been evaluated at Rs357.6 million. A measure of Rs226.8 million has just been discharged, while service of the inside has mentioned Rs130.6 million extra assets as of August 29. The harm to public property has been evaluated at Rs5 million by the Capital Development Authority. The hardware of state-possessed Pakistan Television was likewise harmed while protestors consumed a police vehicle other than harming 17 others. Up until now, 717 people have been harmed including 202 police staff and three nonconformists additionally lost their lives, as indicated by authority gauges. Moreover, Khan ended his dharna in the capital city when the terrorists attacked and martyred the innocent children of Pakistan Army Public School. The cost of this terrorist attack was the causalities of more than 150 students and teachers. Internal political instability directly influences the external interference and obstructs the state development (Rana, 2014).

\section{Affects the educational sector}

Through education, the knowledge of society, country, and of the world is passed on from generation to generation. In democracies, through education, children and adults are supposed to learn how to be active and effective citizens. Empowered individuals, societies, countries by education are taking an edge over individuals stand on the bottom 
pyramid of growth. Countries with highly educated people are less inclined to political violence. The opportunity cost for an unemployed young person with low levels of education to be involved in a rebellion or a riot is too high is lower than for an unemployed young person with higher levels of education. Educational activities were delayed after summer holidays on 11 August 2014 but schools remain closed up to August and after that dates were changed. All educational institutions were closed for more than one month to accommodate the ongoing agitation by chiefs of Pakistan Tehreek-i-Insaf and Pakistan Awami Tehreek which eventually leading to losses in the education sphere. Schools have stayed closed with youngsters losing significant learning time. Police authorities from Punjab and AJK have been incidentally utilizing the schools' premises and 30,000 governmental educational institutes were closed (Javed \& Mamoon, 2017). The dread is that the legislature will attempt to take cover behind the political unrest to shroud its wastefulness on the economic front.

\section{Lack of accountability}

The spectra of defilement are becoming more grounded without genuine responsibility. The responsibility which goes for fortifying the underlying foundations of vote-based system is inadequate in our nation. It is a kind of downpour which is debilitating the popular government to its underlying foundations and representing an extraordinary danger. Powerless establishments and medieval frameworks are additionally a noteworthy piece of precariousness. A rupee, if appropriately contributed, can bring 10pc returns however in the event that just half rupee is contributed and the other half is taken for individual use, at that point we will finish up with negative returns and, eventually, a wavering economy(Javed \& Mamoon, 2017).

\section{Civil disobedience}

Agitational politics is related to mass development, proposed to cause a complete halt of commercial exercises and frequently results in intimidation, viciousness, and harm to both open and private properties. The act of civil disobedience leads the nation toward the devastation. The government faces difficulties to handle the protesters to damage the public property and difficult to manage the security matters especially in time of terrorist activities. In the case of August 2014, Imran Khan lunched doesn't pay taxes movement that had given a call for disobedience as a major aspect of the PTI's agitation against the government. Khan, chief of Pakistan Tehreek i Insaaf, has gathered a large number of anti-government dissidents to stop paying taxes and bills to illegitimate government and also urged the acts of civil disobedience until the resignation of PM Nawaz Sharif (Times, 2014). The individuals who invite and instigate the common people to disrupt the law are abusing the terms liberty and freedom to accomplish their own interests. The guarantee of peaceful agitation and sit-in has not been kept.

\section{Result and Conclusion}

Anyhow the issue, agitational politics, is not normal for democracy over the world. Pakistani ideological groups do not sort out the issues which straightforwardly sway their citizens. It is additionally self-hurting, that ideological groups once in a while use challenge to take intense positions on issues, there is equivocalness present in their positions that no distributed statement can get out. There is a period for governmental issues, and there is the ideal opportunity for mankind. For the ideological groups that speak to Pakistan's 200 million, the last is only a device to do the previous. Until this prioritization changes, no change will come, regardless of who possesses the passageways of intensity. This sits-in culture has pulled in an enormous slander in Pakistan including some neighboring nations for that political and religious turmoil has rendered Pakistan into an extraordinary misfortune both financially and politically. Political solidness assumes a significant job in keeping society incorporated and in keeping up authenticity inside the state. The dependability of the political framework affects the procedure of country and state building. The way of life of despises and brutality is lethal. This ought to be taken as a reminder. The state is in threat with adversaries inside and without. Walks and sit-in play ruin with our economy and mind. Positive reasoning just could be our expectation. The foe is at our door.

Political parties made guarantees with masses in open gatherings and media to explain vitality emergency, constituent changes, debasement, joblessness, issues identified with lawfulness, training, wellbeing, value climb, and expansion also, and neediness. This culture has been propagating by political parties and other groups because they have the only solution to get their demands. Due to the lack of organized political units, politicians point out each other and create valid arguments, no matter what 's the outcomes of these arguments. Long-standing, established political and social challenges have molded every national foundation and economy today. To this way, agitational politics directly hurts the image of the country and also destabilizing the economic spheres. Political parties use their slogans to gain public support. Radicalism and dismissal for the law has emphasized unnecessarily since the 1980s 
in our nation. This radiates fundamentally from our degenerate and insufficient organization, police and lawful framework. Government officials and individuals of impact exploit their shortcoming to unreasonably advance their own advantages. To intensify our torments, fear-based oppression has taken its underlying foundations somewhere down in our social structure that has demolished our economy and made our excellent nation scourge of the earth.

Lamentably, neither our legislators nor our country has woken up to take awareness of these hard substances. We all have neglected to join together and join our hands to conquer these dangers. Our political experts are as yet occupied with their own fights and journey for power. Two-thirds larger part cannot avoid the toppling of law based chosen government. A road tumult by a couple of thousand demonstrators can toss a larger part government helpless before the restriction. It can consign it to a position where the running government can be mortified by the restriction in a broadcast joint session and compelled to submit peacemaking sentiments. Agitational politics, 2014 dharna by PTI and PAT, was only a dramatization to pressurize the government and to trick the general population at the expense of open burden and gigantic misfortune to the national economy. Pakistan needs administration which is equipped for developing the institution and needs solidarity and unity. Political stability plays an important role to keep society integrated and maintain legitimacy within the state. The stability of the political system has direct effects on the process of nation and state building.

\section{References}

Ahmad, I. (2014, september 10). The Nation. Retrieved Junary 05, 2019, from https://nation.com.pk: https://nation.com.pk/10-Sep-2014/implications-of-the-protests

Akhter, K. (2015, May 20). Pakistan Today. Retrieved March 8, 2019, from https://www.pakistantoday.com: https://www.pakistantoday.com.pk/2015/05/20/politics-of-agitation-4/

Arowolo, D. (2011). Nigeria's Federalism and the Agitation for Resource Control in the Niger-Delta Region, OIDA International Journal of Sustainable Development, 2(7), 83-88

Bakht, N. (2009). Veiled Objection to the Niqb, University of Ottawa- Common Law Section. Accessed from http://ssrn.com/abstract=1476029.

Chowdhury, M.H. (2011). The Relationship Between Economic Growth and Transformation of Democracy of Bangladesh, East West University; University of Dhaka. Accessed from http://ssrn.com/abstract=2006670.

Elaine, S. T. (2010). Does Democracy Reduce Inequality? Franchise Extension in Britain and the Kuznets Curve, University of London. accessed from http://ssrn.com/abstract=1554252.

Javed, R., \& Mamoon, D. (2017). Political Instability and Lessons for Pakistan: Case Study of 2014 PTI Sit in protests.

Kronstadt, K. A., \& Kumar, S. (2014). Pakistan Political Unrest: In Brief. Congressional Research Service .

News, S. (2014, August 20). Samaa News. Retrieved April 28, 2019, from https://www.samaa.tv: https://www.samaa.tv/news/2014/08/imran-ties-negotiation-to-nawaz-resignation/

Rana, S. (2014, September 8). Tribune. Retrieved December 6, 2018, from https://tribune.com.pk: https://tribune.com.pk/story/759212/sit-ins-paralyse-islamabad-slow-down-progress/

Times, I. (2014, August 18). The Irish Times. Retrieved march 18, 2019, from https://www.irishtimes.com: https://www.irishtimes.com/news/ireland/irish-news/imran-khan-calls-for-mass-civil-disobedience-inpakistan-until-pm-steps-down-1.1899830

Wasim, A. (2016, November 13). Dawn. Retrieved April 14, 2019, from https://www.dawn.com: https://www.dawn.com/news/1296017 